Research Article

\title{
INVITRO EVALUATION OF FUNGICIDES AND BOTANICALS AGAINST FUSARIUM OXYSPORUM F.SP. CUBENSE OF BANANA
}

\author{
B. Pant ${ }^{1}$, S. Manandhar ${ }^{1}$, C. Manandhar ${ }^{1}$ and S. Baidhya ${ }^{2}$
}

\begin{abstract}
Fusarium wilt caused due to Fusarium oxysporum f.sp cubense is one of the most destructive diseases of banana worldwide. Three fungicides namely Bavistin (Carbendazim 50\% WP), Sectin (Fenamidone 10\%+Mancozeb 50\%), Dhanucop (Copper oxychloride 50\% WP) in two concentrations (100 and 200ppm) and three botanicals (Azadirachta indica, Justicia adhatoda and Eucalyptus globules) at (5 and 10\%) concentration were evaluated against $F$. oxysporum under laboratory condition following poison food technique. The design of the experiment was completely randomized design with four replications and seven treatments including control. Observations were taken at 24 hours interval upto 144 hours for the assessment of their inhibitory effect. Isolates of pathogen used in this study were collected from Chitwan district of Nepal. All the fungicide showed effectiveness in decreasing the fungal growth at increased concentrations. Total inhibition of the fungal growth at both concentrations was found in case of bavistin whereas sectin showed 21.94 and $34.48 \%$ inhibition at 100 and $200 \mathrm{ppm}$ concentration, respectively. In case of botanicals, Eucalyptus showed highest percent inhibition (36.67\%) followed by Asuro (9.10\%) and Neem (5.32\%) at 10\% concentration. Fungicide Bavistin and Masala among botanicals were proved to be the best which inhibited the fungal growth in all concentrations.
\end{abstract}

Key words: Botanicals, fungicides, Fusarium oxysporum f.sp. cubense

\section{INTRODUCTION}

Banana is considered one of the major fruits in social and economic respect in Nepal and stands fourth position after citrus, mango and apple in term of fruit growing area in the country (K.C. et al., 2009).

${ }^{1}$ Scientist at Plant Pathology Division, Nepal agriculture Research Institute, Nepal agricultural Research Council

${ }^{2}$ Senior Scientist at Plant Pathology Division, Nepal Agriculture Research Institute, Nepal Agricultural Research Council

Email for correspondence:bimalapant2000@gmail.com 
Malbhog, an indigenous banana variety of Nepal valued for its flavor and delicacy suffers production losses due to Fusarium oxysporum f.sp. cubense. Fusarium wilt of several agricultural and horticultural crops is caused by $F$. oxysporum, a pathogenic fungus common in soil around the world (Mongkutkarn and Kasem, 2016). Pathogen enters the plants through the roots and colonizes the xylem vessels thereby blocking the flow of water and nutrients (Ploetz and Churchill, 2011).Yellowing of oldest leaves or a longitudinal splitting of the lower portion of the outer leaf sheaths on the pseudostem is the first external symptoms of panama wilt of banana. Evidence suggests that $F$. oxysporum f. sp.cubense originated in Southeast Asia (Ploetz and Pegg, 1997) and from there was disseminated rapidly throughout the world with infected rhizomes (Stover, 1962). Infected rhizomes or suckers and adhering soil are the means of transmission of panama wilt from one country or growing region to another region. These rhizomes and suckers often did not exhibit symptoms (Moore et al., 1995). F. oxysporum is spread from infested to non-infested areas between fields or within production areas in contaminated water, and with farm equipment, shoes and vehicles (Ploetz, 1994).

Chemical control of Panama wilt of banana has received little attention in the past 40 years although fungicides remain an important part of disease control strategies. At present, botanical fungicides are gaining importance as they are considered as an alternative source for chemicals in the management of soil borne pathogens. The active ingredient present in botanicals may directly act on the pathogen or induce systemic resistance in the host plants resulting in the reduction of disease development (Yulier and Toyata, 2015). For the management of various plant diseases including panama wilt of banana, botanicals are considered eco-friendly, less expensive and easily available (Akila et al., 2011). Hence, in the study different chemical fungicides and botanical extractions were included for testing the efficacy level to control the panama disease of banana.

\section{MATERIALS AND METHODS}

An in-vitro experiment was conducted at Plant Pathology Division of Nepal Agricultural Research Council to find out the effective fungicides and botanicals against Fusarium oxysporum f. sp. cubense. The experiment was conducted in Complete Randomized design with four replications and seven treatments including control. Three fungicides (Bavistin: Carbendazim 50\% WP, Sectin: Fenamidone 10\%+Mancozeb 50\%WP) and (Dhanucop: Copper oxychloride 50\% WP) with two concentrations viz., 100 and $200 \mathrm{ppm}$ and three botanical extracts such as Neem (Azadirachta indica), Masala (Eucalyptus globulus) and Asuro (Adhatoda vasica) with 5 and $10 \%$ concentrations were incorporated to Potato Dextrose Agar medium for inoculation of the Fusarium in sterilized petridishes. For botanical extract, leaves were grinded in mixture grinder with equal amount of sterilized water and heated in hot water bath at 100 degree centigrade for 15 minutes. The grinded material was filtered through muslin cloth to get stock solution considered as $100 \%$ concentration $(1: 1 \mathrm{w} / \mathrm{v})$. Five and ten $\mathrm{ml}$ of stock solution was mixed with 95 and $90 \mathrm{ml}$ of 
sterilized PDA medium respectively, for making 5 and 10 percent concentration solution. The isolated pathogen was grown on potato dextrose agar medium prior to the setting of the experiment. Twenty $\mathrm{ml}$ of poisoned medium was poured in each sterilized petriplate and suitable checks were maintained without addition of fungicides and botanicals. An isolate of Fusarium oxysporum f.sp cubense (Foc) used in this study were isolated from banana plants of Chitwan district of Nepal. Four millimeter of seven days old fungal disc was taken from the periphery of the culture and was placed in the centre of the poisoned medium aseptically and incubated at $25^{\circ} \mathrm{C}$. The diameter of the colony was measured in two directions and the average was recorded after incubation for five to six days.

Percent inhibition of the fungus was calculated by using the following formula (Vincent, 1947)

$\mathrm{I}=(\mathrm{C}-\mathrm{T} / \mathrm{C}) \times 100$

Where,

$\mathrm{I}=$ Percent inhibition.

$\mathrm{C}=$ Growth of the pathogen in control plate.

$\mathrm{T}=$ Growth of the pathogen in treated plate.

Statistical package IRRI STAR was used for the analysis of variance to test the significance of treatment effect on mycelia growth and sporulation of Fusarium oxysporum. Least significant difference test was used to compare the values of significant treatment means at $1 \%$ level of significance.

\section{RESULTS AND DISCUSSION}

Different chemicals and botanicals were tested against $F$. oxysporum f.sp. cubense following poisoned food technique. Fungicides were tested at 100 and $200 \mathrm{ppm}$ and botanicals at 5 and $10 \%$ concentrations each. The observations on colony diameter and percent inhibition of colony growth over control are presented in Table 1,2 and Fig. 1. A gradual increase of fungal mycelia growth was observed with increasing periods of incubations in control as well as all other treatments. The maximum radial growth of fungus at 120 hours was observed in control $(7.9 \mathrm{~cm})$ followed by those treated with Copper oxychloride (COC) 100 ppm $(7.72 \mathrm{~cm})$, COC 200 ppm (7.53), Fenamidone 10\%+Mancozeb 50\% 100 ppm $(6.22 \mathrm{~cm})$, Fenamidone $10 \%+$ Mancozeb $50 \%$ WP 200 ppm $(5.22 \mathrm{~cm})$. In case of botanicals, maximum radial growth of fungus after same hour of incubation was observed in Neem $10 \%(7.55 \mathrm{~cm})$ followed by Neem 5\% $(7.42 \mathrm{~cm})$, Asuro 10\% $(7.25 \mathrm{~cm})$, Asuro 5\% $(7.15$ $\mathrm{cm})$, Eucalyptus $5 \%(5.78 \mathrm{~cm})$ and Eucalyptus $10 \%(5.07 \mathrm{~cm})$. Carbendazim 50\% WP, completely inhibited the mycelia growth of the fungus (100\%) followed by Fenamidone $10 \%+$ Mancozeb $50 \%$ WP $(21.94 \%)$, COC $(3.13 \%)$ at $100 \mathrm{ppm}$. Whereas at $200 \mathrm{ppm}$, Fenamidone $10 \%+$ Mancozeb $50 \%$ WP showed $34.48 \%$ inhibition followed by COC (5.64\%). 
The results showed that, effect of plant extracts on the fungal growth inhibition was also significant than control. In eucalyptus, $36.67 \%$ inhibition was found which was most effective and significantly superior in inhibiting mycelia growth of $F$. oxysporum and this was followed by Asuro (9.10\%) and Neem (5.32\%) inhibition at 10\% concentration.

In this study, two concentrations of Carbendazim 50\% WP completely suppressed mycelia growth of $F$. oxysporum f.sp. cubense. This result is in agreement with Soma et al., 2008 who found that Bavistin and Vitavax showed complete inhibition of pathogen $F$. oxysporum f.sp. cubense at 100 and $200 \mathrm{ppm}$. There was complete inhibition of mycelia growth of Fusarium sp. when treated with fungicide Bavistin. Singh and Jha, 2003 also found Carbendazim as the most effective fungicide against $F$. oxysporum f.sp. ciceris under in vitro conditions. Sectin (Fenamidone 10\%+Mancozeb 50\% WP) was found to be less effective than Bavistin (Carbendazim 50\% WP) but possesses more inhibition capacity than Copper oxychloride. The efficacy of Copper oxychloride and neem was not found significantly different. Similarly, efficacy of Sectin (Fenamidone 10\%+Mancozeb 50\% WP) and Eucalyptus was also not significant with each other (Table $1 \& 2$ ). Hence, these botanical products can be used as alternative for Copper oxychloride and Sectin (Fenamidone $10 \%+$ Mancozeb 50\% WP) to reduce the radial growth of pathogen. Similarly, Asuro was found more effective than $\mathrm{COC}$ in term of inhibition of the pathogen.

There was no significant difference on inhibition of mycelium growth of pathogen in application of 5 and $10 \%$ of Asuro and Neem whereas there was significant difference on inhibition of colony growth of pathogen when the concentration of eucalyptus was increased to $10 \%$ (Table 2). The present results of this study exhibit the radial growth of Fusarium sp. was inhibited in vitro by leaf extracts of Eucalyptus, Neem and Asuro, suggesting the presence of antifungal substances in the plant tissue, which agrees with the results reported by other workers on different pathogens and plants ((Tewari and Nayek, 1991; Alabed et al., 1993; Qasem et al., 1996; Amadioha, 1998; Amadioha, 2003). Results also showed that Eucalyptus leaf extract, at $10 \%$ concentration was significantly superior over $5 \%$ concentration but the similar trend was not found with increasing the concentration of leaves extract of Neem and Asuro to inhibit the growth of pathogen (Table 2). Results obtained with Eucalyptus (Masala) leaf extract on radial growth of Fusarium oxysporum f.sp. cubense indicated that it was effective in reducing growth of fungus at both 5 and $10 \%$ concentrations as compared to Asuro and Neem leaf extracts. The inhibitory effects of Eucalyptus on Fusarium oxysporum f.sp cubense has also been previously reported in an in vitro assay (Mengane et al. 2014).

\section{CONCLUSION}

From this study, it is concluded that chemical fungicide Bavistin (Carbendazim 50\% WP) and botanical product, Masala (Eucalyptus globulus) are found effective to suppress the growth of pathogen $F$. oxysporum f.sp. cubense of banana. The level of inhibition of 
pathogen is increased with increasing the level of concentration of leaf extract of Eucalyptus. Further green-house and field trials are necessary for evaluating these chemicals and botanicals against the pathogen for additional confirmation. The botanical extraction can also be used as alternative application for the chemical fungicides.

\section{ACKNOWLEDGEMENT}

We would like to thank the staffs of Plant Pathology Division NARC for their continuous help and guidance during the research period.

\section{LITERATURE CITED}

Akila, R., L. Rajendran, S. Harish, K. Saveatha, T. Raguchandar and R. Samiyapaan. 2011. Combined applications of botanical formulations and biocontrol agents for the management of Fusarium oxysporum f.sp. cubense (FOC) causing Fusarium wilts in banana. Biological control. 57: 115-183.

Al-Abed A.S., J.R. Qasem and H. A. Abu-Blam. 1993. Antifungal effects of some common wild- plants species on certain plant pathogenic fungi. Dirasat (Pure and Applied Science). 20:149-158.

Amadioha, A.C. 1998. Fungi toxic activity of extracts of Azadirachta indica and Xylopia aethiopica on Colletotrichum lindemuthianum in Cowpea. Journal of Herbs, Spices and Medicinal Plants. 6:33-40.

Amadioha., A.C. and P.N. Uchendu. 2003. Post-harvest control of tomato fruit rot caused by Fusarium solani with extracts of $A$. indica. Discovery and Innovation. 15(1-2):8386.

KC, R.B., Durga, M. Gautam and S. Tiwari. 2009. Use of ethipone and indigenous plant material in ripening banana in winter.Nepal.Agric.Res. J.9:113-117.

Mengane, S. and S. Kamble. 2014. Bioefficacy of plant extracts on Fusarium oxysporum f.sp. cubense causing panama wilt of banana. IJPBS (India). 4(3):24-27p

Mongkutkarn U. and K. Soytong. 2016. Isolation, identification, and Pathogenicity test from Fusarium oxysporum f.sp. cubense causing banana wilt. International Journal of Agricultural Technology. 12(7.2):2181

Moore, N.Y., S. Bentley., K.G. Pegg and D.R. Jones. 1995. Fusarium wilt of bananas. Musa disese fact sheet no. 5. France: INIBAP

Ploetz, R.C. 1994. Panama disease: return of the first banana menace. Int. J. Pest Manage. 40:326-336. 
Ploetz, R.C. and A.C.L Churchill. 2011. Fusarium wilt: The banana disease that refuses to go away. In: I. Van Den Bergh, M. Smith. R. Swenenn and C. Hermanto (eds.), Proceedings of International IHSHPromusa Symposium on Global Perspectives on Asian Challenges.

Ploetz, R.C. and K.G. Pegg. 1997. Fusarium wilt of banana and Wallace's line: was the disease original restricted to his Indo-Malayan region? Australas. Plant Pathol. 26:239-249.

Qasem, J.R., H.A. Abu-Blam. 1996. Fungicidal activity of some common weed extracts against different plant pathogenic fungi. Journal of Phytopathology. 144:157-161.

Singh, D.K. and M.M. Jha. 2003. Effect of fungicidal treatment against chickpea wilt caused by F. oxysporum f.sp.ciceris. J. Applied Biology. 13(2):41-45.

Soma, D., S. Sapana and A. Ashok. 2008. Efficacy of fungicides on mycelia growth and enzyme production on Rhizoctonia solani and Fusarium oxysporum. Annals of Plant Protection Sciences. 16(1):135-138.

Stover, R.H. 1962. Fusarium wilt (Panama disease) of bananas and other Musa species. Commonwealth mycological institute, Kew, Surrey, U.K.

Tewari, S.N. and M. Nayek. 1991. Activity of four plant leaf extracts against three fungal pathogens of rice. Trap. Agric. (Trinidad). 68:373-375.

Vincent, J.M. 1947. Distoration of fungal hyphae in the presence of certain inhibitors. Nature. 159:850

Yuliar, N.Y.A. and K. Toyata. 2015. Recent trends in control methods for bacterial wilt diseases caused by Ralstonia solanacearum. Microbes and environments. 30(1):111. 
Table 1. Effect of Fungicides and botanical extract on radial growth $(\mathrm{cm})$ of Fusarium oxysporum during 2019

\begin{tabular}{llllll}
\hline Treatments & $\mathbf{2 4 h r s}$ & $\mathbf{4 8 h r s}$ & $\mathbf{7 2 h r s}$ & $\mathbf{9 6 h r s}$ & $\mathbf{1 2 0 h r s}$ \\
\hline Control & $1.65^{\mathrm{a}}$ & $3.33^{\mathrm{a}}$ & $4.55^{\mathrm{a}}$ & $6.10^{\mathrm{a}}$ & $7.97^{\mathrm{a}}$ \\
Bavistin 100ppm & $0.00^{\mathrm{h}}$ & $0.00^{\mathrm{g}}$ & $0.00^{\mathrm{h}}$ & $0.00^{\mathrm{g}}$ & $0.00^{\mathrm{i}}$ \\
Bavistin 200 ppm & $0.00^{\mathrm{h}}$ & $0.00^{\mathrm{g}}$ & $0.00^{\mathrm{h}}$ & $0.00^{\mathrm{g}}$ & $0.00^{\mathrm{i}}$ \\
Sectin 100ppm & $1.15^{\mathrm{def}}$ & $2.2^{\mathrm{e}}$ & $3.17^{\mathrm{f}}$ & $4.20^{\mathrm{e}}$ & $6.22^{\mathrm{f}}$ \\
Sectin 200ppm & $1^{\mathrm{g}}$ & $1.70^{\mathrm{f}}$ & $2.73^{\mathrm{g}}$ & $3.58^{\mathrm{f}}$ & $5.22^{\mathrm{h}}$ \\
Copper oxychloride 100ppm & $1.27^{\mathrm{c}}$ & $2.60^{\mathrm{c}}$ & $4.09^{\mathrm{c}}$ & $5.50^{\mathrm{b}}$ & $7.72^{\mathrm{b}}$ \\
Copper 0xychloride 200ppm & $1.48^{\mathrm{b}}$ & $2.85^{\mathrm{b}}$ & $4.30^{\mathrm{b}}$ & $5.62^{\mathrm{b}}$ & $7.53^{\mathrm{bc}}$ \\
Neem 5\% & $1.18^{\text {cdef }}$ & $2.45^{\mathrm{cd}}$ & $3.85^{\mathrm{d}}$ & $5.25^{\mathrm{c}}$ & $7.42^{\mathrm{cd}}$ \\
Neem 10\% & $1^{\mathrm{g}}$ & $1.15^{\mathrm{e}}$ & $3.60^{\mathrm{e}}$ & $5.05^{\mathrm{d}}$ & $7.55^{\mathrm{bc}}$ \\
Asuro 5\% & $1.23^{\mathrm{cd}}$ & $2.65^{\mathrm{bc}}$ & $3.88^{\mathrm{d}}$ & $5.15^{\mathrm{cd}}$ & $7.15^{\mathrm{e}}$ \\
Asuro 10\% & $1.10^{\mathrm{efg}}$ & $2.42^{\mathrm{cd}}$ & $3.67^{\mathrm{e}}$ & $5.03^{\mathrm{d}}$ & $7.25^{\mathrm{de}}$ \\
Eucalyptus 5\% & $1.20^{\text {cde }}$ & $2.25^{\mathrm{de}}$ & $3.10^{\mathrm{f}}$ & $4.10^{\mathrm{e}}$ & $5.78^{\mathrm{g}}$ \\
Eucalyptus 10\% & $1.07^{\mathrm{fg}}$ & $1.88^{\mathrm{f}}$ & $3.73^{\mathrm{g}}$ & $3.52^{\mathrm{f}}$ & $5.07^{\mathrm{f}}$ \\
CV & 7.61 & 7.96 & 3.19 & 3.33 & 2.77 \\
LSD & 0.11 & 0.23 & 0.13 & 0.19 & 0.22 \\
P<0.01 & $* *$ & $* *$ & $* *$ & $* *$ & $* *$ \\
\hline
\end{tabular}

Note: Values in the same column followed by similar letter are not significantly different.

Table 2. Effect of Fungicides and botanical extract on percent inhibition (cm) of Fusarium oxysporum during 2019

\begin{tabular}{llllll}
\hline Treatments & $\mathbf{2 4 h \mathbf { h }}$ & $\mathbf{4 8 h \mathbf { h }}$ & $\mathbf{7 2 h r s}$ & $\mathbf{9 6 h r s}$ & $\mathbf{1 2 0 h r s}$ \\
\hline Control & $0.00^{\mathrm{g}}$ & $0.00^{\mathrm{h}}$ & $0.00^{\mathrm{h}}$ & $0.00^{\mathrm{g}}$ & $0.00^{\mathrm{i}}$ \\
Bavistin 100ppm & $100^{\mathrm{a}}$ & $100^{\mathrm{a}}$ & $100^{\mathrm{a}}$ & $100^{\mathrm{a}}$ & $100^{\mathrm{a}}$ \\
Bavistin 200ppm & $100^{\mathrm{a}}$ & $100^{\mathrm{a}}$ & $100^{\mathrm{a}}$ & $100^{\mathrm{a}}$ & $100^{\mathrm{a}}$ \\
Sectin 100ppm & $30.33^{\mathrm{cd}}$ & $36.13^{\mathrm{cd}}$ & $30.22^{\mathrm{c}}$ & $31.13^{\mathrm{c}}$ & $21.94^{\mathrm{d}}$ \\
Sectin 200ppm & $39.34^{\mathrm{b}}$ & $48.75^{\mathrm{b}}$ & $40.09^{\mathrm{b}}$ & $41.37^{\mathrm{b}}$ & $34.48^{\mathrm{b}}$ \\
Copper 0xychloride 100ppm & $22.61^{\mathrm{e}}$ & $21.64 \mathrm{f}^{\mathrm{g}}$ & $10.15^{\mathrm{f}}$ & $9.81^{\mathrm{f}}$ & $3.13^{\mathrm{h}}$ \\
Copper oxycloride 200ppm & $10.57^{\mathrm{f}}$ & $14.22^{\mathrm{g}}$ & $5.47^{\mathrm{g}}$ & $7.75^{\mathrm{f}}$ & $5.64^{\mathrm{gf}}$ \\
Neem 5\% & $28.68^{\mathrm{cde}}$ & $26.26^{\mathrm{ef}}$ & $15.36^{\mathrm{ef}}$ & $13.87^{\mathrm{e}}$ & $6.89^{\mathrm{fg}}$ \\
& & & & &
\end{tabular}




\begin{tabular}{llllll}
\hline Treatments & $\mathbf{2 4 h \mathbf { h r }}$ & $\mathbf{4 8 h \mathbf { h r }}$ & $\mathbf{7 2 h r s}$ & $\mathbf{9 6 h r s}$ & $\mathbf{1 2 0 h r s}$ \\
\hline Neem $10 \%$ & $39.34^{\mathrm{b}}$ & $35.29^{\mathrm{d}}$ & $20.88^{\mathrm{d}}$ & $17.15^{\mathrm{de}}$ & $5.32^{\mathrm{g}} \mathrm{h}$ \\
Asuro 5\% & $33.18^{\mathrm{bc}}$ & $20.31^{\mathrm{fg}}$ & $14.82^{\mathrm{e}}$ & $15.58^{\mathrm{de}}$ & $10.34^{\mathrm{e}}$ \\
Asuro $10 \%$ & $25.55^{\mathrm{de}}$ & $26.97^{\mathrm{ef}}$ & $19.21^{\mathrm{d}}$ & $17.63^{\mathrm{d}}$ & $9.10^{\mathrm{ef}}$ \\
Eucalyptus 5\% & $27.30^{\text {cde }}$ & $32.23^{\mathrm{de}}$ & $31.87^{\mathrm{c}}$ & $32.75^{\mathrm{c}}$ & $27.57^{\mathrm{c}}$ \\
Eucalyptus 10\% & $34.74^{\mathrm{bc}}$ & $43.60^{\mathrm{bc}}$ & $40.11^{\mathrm{b}}$ & $42.20^{\mathrm{b}}$ & $36.37^{\mathrm{b}}$ \\
CV & 14 & 13.78 & 7.17 & 7.72 & 7.73 \\
LSD & 7.57 & 7.66 & 3.37 & 3.64 & 3.06 \\
P $<0.01$ & $* *$ & $* *$ & $* *$ & $* *$ & $* *$ \\
\hline
\end{tabular}

Note: Values in the same column followed by similar letter are not significantly different.

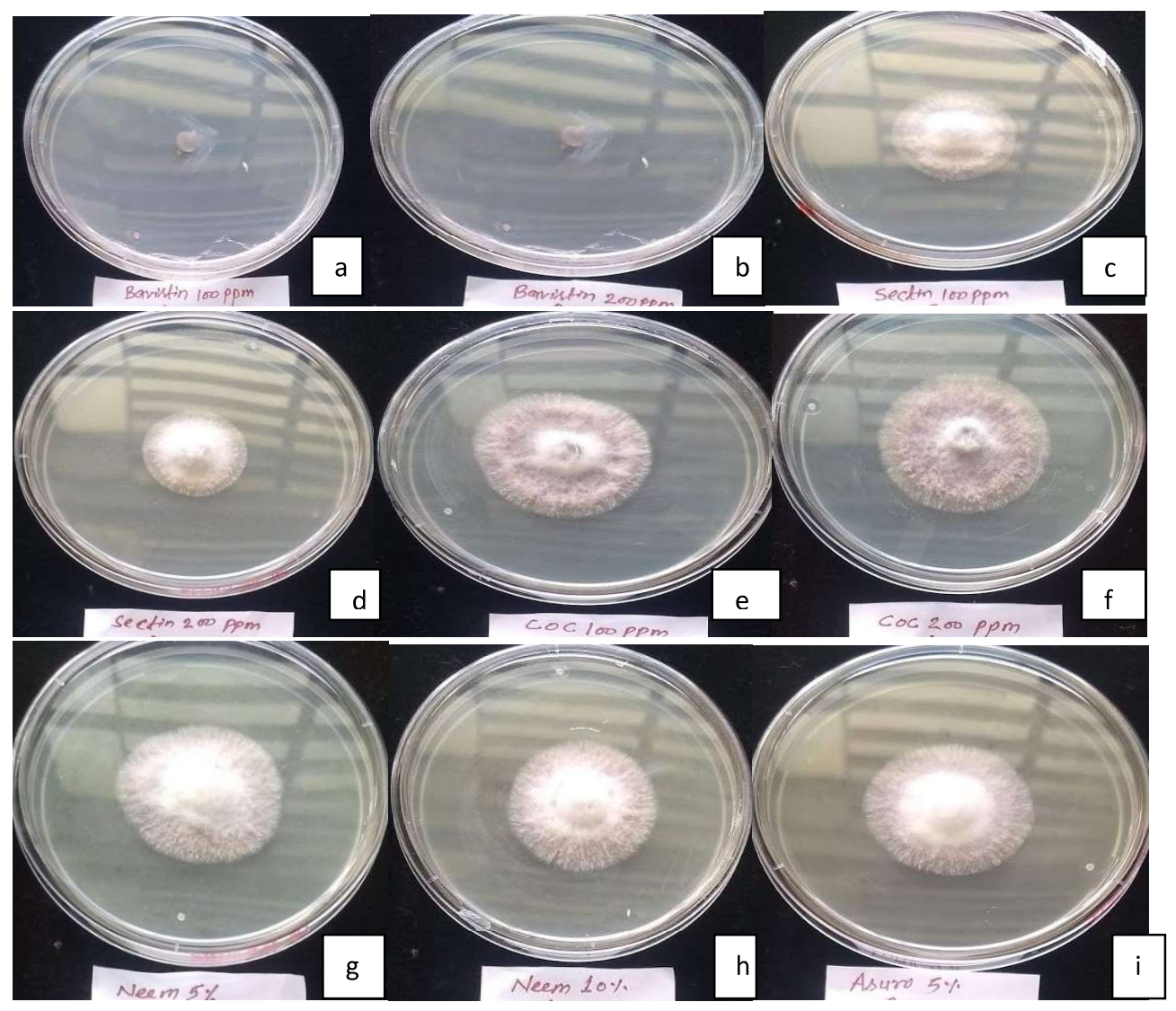




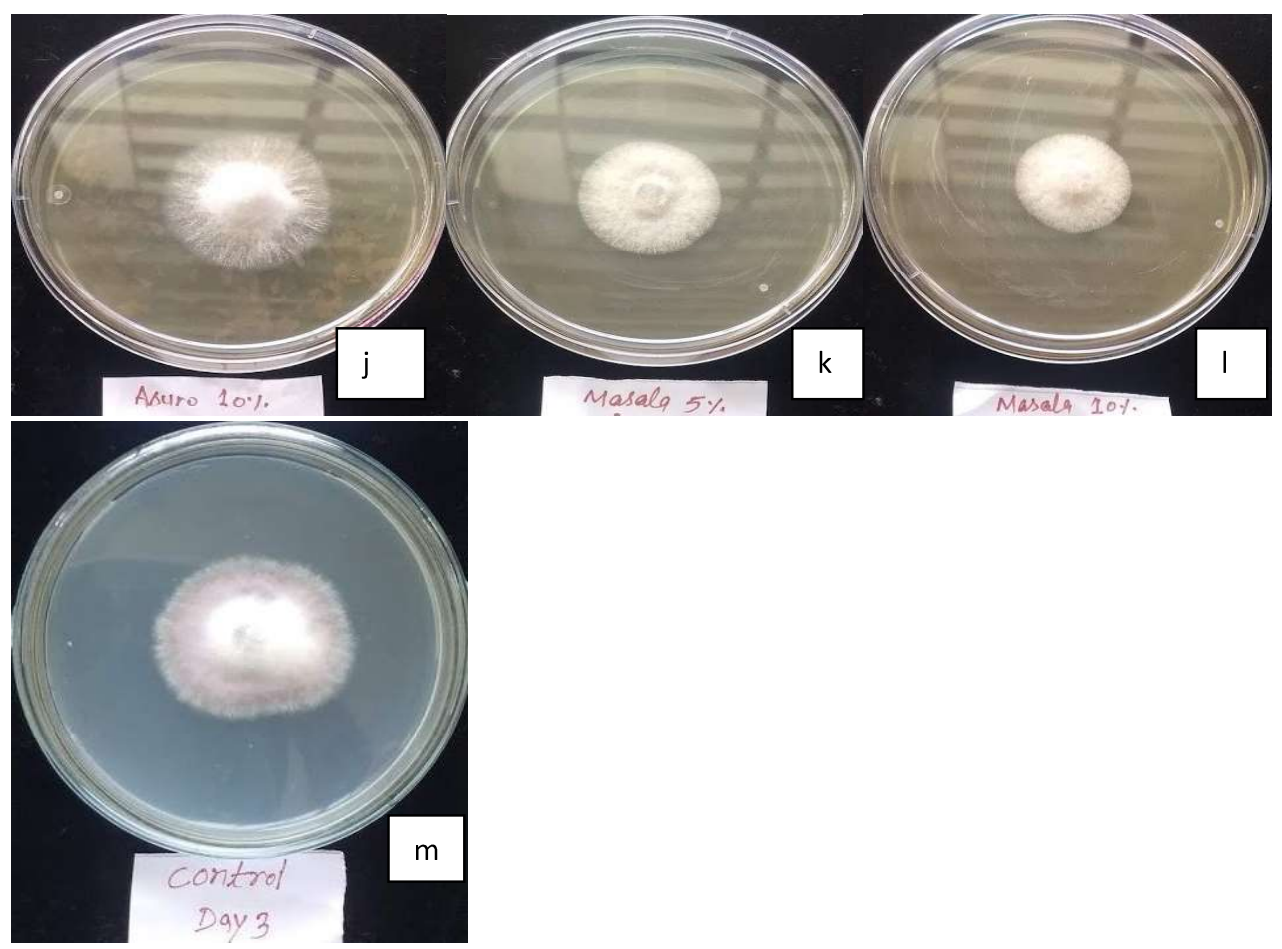

Fig. 1: Inhibitory effect of fungicides and botanical extracts on radial growth of Fusarium oxysporum
a) Bavistin $100 \mathrm{ppm}$,
b) Bavistin $200 \mathrm{ppm}$,
c) Sectin $100 \mathrm{ppm}$,
d) Sectin $200 \mathrm{ppm}$,
e) Copper oxychloride $100 \mathrm{ppm}$,
g) Neem 5\%,
h) Neem 10\%,
f) Copper oxychloride $200 \mathrm{ppm}$,
j) Asuro 10\%,
k) Masala 5\%,
i) Asuro 5\%,
m) Control
1) Masala $10 \%$ and 